\title{
Transforming Positive Attitude of Pre Service Teachers Towards Inclusive Education By Cooperative Learning Technology
}

\author{
${ }^{{ }^{*} 1}$ Albina M. Sharafieva, ${ }^{2}$ Iskander E. Yarmakeev, ${ }^{3}$ Rimma M. Akhmadullina, ${ }^{4}$ Nelly R. Valiakhmetova \\ 1, 2, 3, 4 Kazan Federal University, Leo Tolstoy Institute of Philology and Intercultural Communication \\ Email: s.albina-lina@mail.ru contact: 89871726806
}

\section{Received: 21st October 2017 Accepted: 16th November 2017, Published: 31st December 2017}

\begin{abstract}
One of modern education tendencies is the active attention to questions of integration of health disability children in educational space of mass comprehensive school. In the way of this process there is a considerable quantity of problems among which often found negative attitude of the teacher to inclusive education. As a result of foreign and domestic scientific research study authors of article provide data on some barriers interfering with forming the positive relation of teachers to this type of education, carry out the theoretical analysis of the reasons of their emergence. According to authors, forming the positive relation to inclusive education has to be taught to future teachers at a stage of high school training by the corresponding substantial and technological support of this process. The main attention in article is paid to identification of cooperative training technology opportunities for the solution of the designated problem. On the example of discipline "Psychology and pedagogical bases of work with students with special educational needs" for students - the undergraduates studying in the Pedagogical education direction are described subjects of occupations, problem tasks within the studied subjects and the relevant most effective structures of the specified technology are compared. According to authors of article, the offered methodical recommendations can be useful to forming the positive relation of future teachers to inclusive education.
\end{abstract}

Keywords: Inclusive Education, Readiness of Future Teacher, Relation, Cooperative Training Technology.

\section{Introduction}

\subsection{Problem Relevance}

Research relevance is caused by special attention of the modern world community and the developed states to the people having health disability (DP). One of the current trends in aspect of this subject is realization of the inclusive education representing integration process of health disability children on educational Wednesday for training together with normally developing peers. Today the inclusive education is the priority direction of social and educational policy development of the majority of the leading countries of the world including Russia. The law "About Education in the Russian Federation" officially entered the concept "inclusive education" as ensuring equal access to education for all students taking into account a variety of special educational needs and individual opportunities and legislatively fixed inclusive practice in education. The special federal state standard is developed for children about DP which came into force in 2016.

Success of an inclusive education first of all is defined by readiness of teachers for realization of inclusive education. Its formation acts as a key problem of the Russian pedagogical education.

\subsection{Explore Importance of the Problem}

More than 21 thousand children are disabled, from them about 13 thousand - are of school age live in the Republic of Tatarstan. The contingent of such children in recent years steadily increases by 150 - 200 people. According to the developed concept of an inclusive education in social policy of the Republic of Tatarstan for 2015 - 2018 in the region actions for realization of the integrated training of children with DP in the conditions of comprehensive schools are carried out. So, in the republic 153 basic comprehensive schools at which since 2016 there began training about 189 children with DP are defined. In September, 2017 in Kazan 5 resource centers of inclusive education focused on children with frustration of autoimmune system will open. In this regard a key task is need of ensuring educational process by professionally trained teachers capable to organize inclusive approach today.

According to opinion of most of researchers' success of inclusive education depends on the whole complex of pedagogical and psychological resources. Their number, in particular, includes professional competence of inclusive teachers; reorganization of system of preparation and professional maintenance of pedagogical shots; change of structure of curricula and space in a class for the purpose of satisfaction of requirements of all categories of children [1]. However, the fundamental factor influencing efficiency of inclusive education in our opinion is not only the level of competence, but also the positive relation of teachers to a phenomenon of inclusive training and disabled children, children with DP in general. 
The purpose of this article - on the basis of the theoretical analysis of scientific research to establish the reasons interfering manifestation of the positive relation of teachers to realization of inclusive education and on this basis to show possibilities of cooperative training technology for the solution of this problem at a stage of vocational training of students.

\section{Materials and Methods}

Methodological basis of a research is: concept of education integration [2], [3], [4]; main approaches to studying the professional readiness [5], [6], [7]; methodical approaches to forming inclusive competence at future teachers [8], [9], [10]. Research methods are: theoretical analysis of scientific and methodical literature, systematization, generalization, comparison.

The carried-out analysis of foreign and domestic researches shows that most teachers show neutral or negative attitude to inclusive education [11]. At the same time, teachers show high extent of acceptance of students with physical disability and smaller - in case of children having behavior and intelligence issues [12]. Results of domestic researches allow specifying that students - future teachers are more positively ready for inclusive education, than already practicing teachers.

As the reasons mediating manifestation of negative attitude of teachers to inclusive education it is possible to allocate the following: 1) existence of psychological (emotional) barriers (fear of imperfection; fear of uncertainty, responsibility, risk not to be capable to control a situation; fear of negative results of training; harm of an inclusive education for other participants of process; unwillingness to change); 2) emotional burning out owing to the large additional volume of work; 3) susceptibility to social installations and professional stereotypes concerning children with DP, the distorted information on them; 4) a lack of professional competences for work of inclusive space (in particular, for the organization of individual and group work taking into account specific features of children with DP; design of creation of an educational route and development of individual programs; forecasting of reaction of behavior and the further relations, forming the subject - the subject relations with children with DP); 5) insufficient degree of forming the professional and personal qualities necessary at work with children with DP (tolerance, resistance to stress, the high level of development of empathy, tactfulness, flexibility in thinking and behavior, creativity, an orientation on innovations, diligence and effectiveness, skill to communicate); 6) low motivation to work with children with DP (there is no installation on altruism, interest in social problems, lack of material stimulation); 7) insufficient extent of the methodical and specialized complex help, knowledge of innovations in inclusive education; 8) absence at the teacher of the right to refuse inclusion of the child with DP in a class; 9) insufficient resource ensuring inclusive education.

\section{Results}

As it was noted above, the most important factor of success of inclusive process is his understanding, acceptance and, in general, the steady positive relation of teachers which developed to it. The relation as result of education, as the most important component of student's personal development, is treated as experience and expression of certain connection which is established between the personality and other people, and also various sides of the world around and which anyway affect her behavior and development [13]. As for forming certain relations at students to these or those objects, the phenomena and processes of pedagogical reality, the cooperative training technology is one of effective ways of the solution of this task. In our opinion, organizing process of interaction on the basis of discussions by the analysis of different beliefs and positions, it can help to overcome negative social installations and stereotypes and to develop own position at students concerning inclusive education. However, a condition for this purpose we consider ensuring problem nature of training necessary.

According to a stated purpose, in our work possibilities of cooperative training technology for the solution of a problem of forming the positive relation of future teachers to practice of inclusive education at examples of the separate training structures are shown [14]. As a substantial basis the program of the course "Psychology and Pedagogical Bases of Work with Students with Special Educational Needs" for students - the undergraduates of the Kazan federal university studying in the Pedagogical education direction is used. In table 1 examples of those of occupations are given; problem tasks; the relevant structures of the specified technology, the most effective for the organization of dialogue, the analysis of positions of members of group, a reflection of own positions, installations and a role of data of structures in forming the positive relation to inclusive education.

Table 1. Examples of use of structures of cooperative technology of training when studying discipline "Psychology and pedagogical bases of work with students with special educational needs" 
Helix Vol. 8(1): 2186-2190

\begin{tabular}{|c|c|}
\hline $\begin{array}{l}\text { The structures of cooperative } \\
\text { technology of training }\end{array}$ & Examples \\
\hline The studied subject & $\begin{array}{c}\text { History of formation and development of national systems vocational } \\
\text { education (sociocultural context) } \\
\text { Problem Statement No. 1. Many decades in Russia there is a restrictive and } \\
\text { patronizing position of society and state in relation to physically disabled } \\
\text { people. What is its essence and negative result? }\end{array}$ \\
\hline $\begin{array}{l}\text { Structure of cooperative } \\
\text { training technology }\end{array}$ & frayer model \\
\hline Role of structure & $\begin{array}{l}\text { deep understanding of a concept a paternalistic position of society and on this } \\
\text { basis understanding of need of its change in modern conditions } \\
\text { Problem Statement No. 2. In "Universal Declaration of Human Rights" the } \\
\text { priority of interests of the personality over interests of society is established. } \\
\text { Whether you consider this statement universal for all life situations, or allow } \\
\text { exceptions when interests of society have to dominate? }\end{array}$ \\
\hline $\begin{array}{l}\text { Structure of cooperative } \\
\text { training technology }\end{array}$ & corners \\
\hline Role of structure & $\begin{array}{l}\text { Understanding of value of the identity of the person, awareness of equal rights } \\
\text { of people from DP and people with normal development }\end{array}$ \\
\hline The studied subject & $\begin{array}{c}\text { Professional activity and identity of the teacher of system of vocational } \\
\text { education }\end{array}$ \\
\hline $\begin{array}{l}\text { Structure of cooperative } \\
\text { training technology }\end{array}$ & Four-box synectics review \\
\hline Role of structure & $\begin{array}{l}\text { helps to deepen and expand the concept "tutor", to realize its specifics and a } \\
\text { humanistic orientation in system of inclusive education } \\
\text { Problem Statement No. } 2 \text {. The teacher working in an inclusive class has to } \\
\text { realize at the same time two educational standards: for ordinary children and } \\
\text { children with DP. Assume how, in your opinion he will solve this problem? }\end{array}$ \\
\hline $\begin{array}{l}\text { Structure of cooperative } \\
\text { training technology }\end{array}$ & Placemat consensus \\
\hline Role of structure & $\begin{array}{l}\text { helps removal of a psychological barrier - fear for negative result of training of } \\
\text { healthy children; enriches with the ideas on the organization of individual and } \\
\text { group work taking into account specific features of children with DP; ideas of } \\
\text { design of an educational route and development of individual programs }\end{array}$ \\
\hline The studied subject & $\begin{array}{l}\text { Psychology and pedagogical escort of trainees with DP in the conditions of } \\
\text { inclusive education } \\
\text { Problem Statement No. } 1 \text {. The remedial classes and compensations existing at } \\
\text { comprehensive schools of Russia at the beginning of the } 21 \text { st century did not } \\
\text { make success and at present practically stopped the existence (to students the } \\
\text { number of questions and information for work with structure of anticipation- } \\
\text { reaction guide is offered) }\end{array}$ \\
\hline
\end{tabular}


Helix Vol. 8(1): 2186-2190

\begin{tabular}{|c|c|}
\hline $\begin{array}{l}\text { Structure of cooperative } \\
\text { training technology }\end{array}$ & anticipation-reaction guide \\
\hline Role of structure & $\begin{array}{l}\text { allows students to realize deeply ambiguity of results of an inclusive education } \\
\text { in conditions when society and an education system are not ready to it neither } \\
\text { in moral nor in material the relations } \\
\text { Problem Statement No. 2. At realization of inclusive forming one of the main } \\
\text { tasks of the teacher there will be a forming the correct attitude of school } \\
\text { students towards children with DP. Offer possible uniforms and methods of } \\
\text { work of teachers at the solution of this problem }\end{array}$ \\
\hline $\begin{array}{l}\text { Structure of cooperative } \\
\text { training technology }\end{array}$ & Think-Write-Round Robin \\
\hline Role of structure & $\begin{array}{l}\text { the empathy, tactfulness, flexibility in thinking and behavior, creativity, an } \\
\text { orientation on innovations, diligence and effectiveness, skill to communicate } \\
\text { focuses students on development of such professional and personal qualities }\end{array}$ \\
\hline The studied subject & $\begin{array}{l}\text { Concepts "norm" and "anomaly" of mental and personal development of the } \\
\text { child } \\
\text { Problem Statement No. 1. In the presence of a large amount of various } \\
\text { interpretations of the concepts "norm" and "anomaly" the teacher has a } \\
\text { problem when it is worth beginning correctional work with the child. Connect } \\
\text { the new information obtained from the teacher with the fact that you knew of } \\
\text { these concepts, offer the new ideas how to define standard of behavior of the } \\
\text { child with DP unlike the healthy child. Whether there will be it the same norm? }\end{array}$ \\
\hline $\begin{array}{l}\text { Structure of cooperative } \\
\text { training technology }\end{array}$ & connect-extend-challenge \\
\hline Role of structure & $\begin{array}{l}\text { allows changing susceptibility to social installations and professional } \\
\text { stereotypes concerning children with DP, cancels the distorted information on } \\
\text { their behavior }\end{array}$ \\
\hline The studied subject & $\begin{array}{l}\text { General and vocational education: integration and differentiation } \\
\text { Problem Statement No. 1. Inclusive education has both undoubted pluses and } \\
\text { minuses now. Opinions of experts in this regard come down to what parents } \\
\text { have the right to choose, where to study the child: at comprehensive school or } \\
\text { special school for children with DP. Try to convince different audiences from } \\
\text { positions of different people of advantage of an inclusive education }\end{array}$ \\
\hline $\begin{array}{l}\text { Structure of cooperative } \\
\text { training technology }\end{array}$ & $\begin{array}{l}\text { RAFT } \\
\text { Role of structure: allows understanding positions of individuals and groups of } \\
\text { experts, to estimate installations and stereotypes of different social groups of } \\
\text { the population concerning an inclusive education }\end{array}$ \\
\hline
\end{tabular}

\section{Discussion}

From one party, the problem of readiness of the teacher for realization of inclusive education finds broad reflection in modern scientific research, in particular, in Cagran B works., Schmidt M., [8], Liventseva N. A. [1], etc. We agree with authors that character of its relation to this kind of activity acts as the fundamental moment defining success of inclusive competence of the teacher. The analysis of researches shows that sharpness of a problem of inclusive education is caused by often found negative relation to it [1]. On the other hand, stating the possible reasons of manifestation of such situation, the existing works do not submit recommendations concerning its decision. Results of the research conducted by us allowed determining the substantial potential of cooperative training technology in aspect of the considered problem.

\section{Conclusions}

Thus, as the theory and practice shows, that forming the positive relation to inclusive education at future 
teachers needs to be begun at a stage of high school training. In this case it is possible to avoid the further problems connected with their professional activity in the conditions of inclusive education, which became a steady tendency in modern Russia. The organization of special scientific research in the field of substantial filling and technological support of process of their vocational training is for this purpose necessary. The options of use of structures of cooperative technology of training offered in this work and also our recommendations can be useful to teachers of the higher school, the students dealing with a problem of forming readiness to carry out inclusive education.

\section{Acknowledgement}

The work is performed according to the Russian Government Program of Competitive Growth of Kazan Federal University

\section{References}

[1] Liventseva, N. A. (2011) Review of modern foreign researches on problems of inclusive education//Psychological science and education. No. 3. Page 114-121

[2] Shipitsyna, L.M. (2004). Integration of health disability children//Education and training of children with development violations. No. 2. Page 7-9.

[3] Ainscow, M. (2010). Developing inclusive education systems: role of organizational cultures and leadership. International Journal of Inclusive Education, p. 401-416.

[4] Kise, J. A. (2006). Differentiated coaching: A framework for helping teachers change. Thousand Oaks, CA: Corwin Press, 117 p.

[5] Shadrikov, EL (2004) New model of the expert: innovative preparation and competence-based approach//the Higher education today. No. 8. Page 2328.

[6] L. Auhadeeva, A. Valiahmetova, R. Akhmadullina, T. Pimenova, I. Salpykova, N. Valiakhmetova, A. Aukhadeev. (2017) Pre-service teachers' communicative competency formation in Russia//11th International Technology, Education and Development Conference. 6-8 March. Valencia, Spain. INTED2017 Proceedings. pp. 774-781

[7] I. Salpykova, R. Akhmadullina, N. Valiakhmetova, A. Valiahmetova (2016) Forming tolerance of schoolchildren in the conditions of cooperative learning (regional aspect)//Edulearn16 Proceedings 8th International Conference on Education and New Learning Technologies July 4th-6th, Barcelona, Spain, pp.7822-7829.

[8] Cagran B., Schmidt M. (2011) Attitudes of Slovene teachers towards the inclusion of students with different types of special needs in primary school//Educational Studies. Vol. 37, Issue 2 pp. 171-195. URL: <http://www.scopus.com/record/display.url>.

[9] Mitchell, D. (2008). What really works in special and inclusive education (Using evidence-based teaching strategies). Routledge, New York, 146 p.

[10] Rimma M. Akhmadullina, Anastasiya S. Sjunina, Indira M. Salpykova, Iskander E. Yarmakeev. (2016) Training of Students - Future Teachers For The Implementation Of Inclusive Education Among Children With Special Health Features//International Journal of Humanities and Cultural Studies, 2016, August 2016 Special Issue, pp.547-555. <http://repository.kpfu.ru/? p_id=137440>

[11] De Boer A., Pijl S.J., Minnaert A. (2011) Regular primary schoolteachers' attitudes towards inclusive education: review of the literature//International Journal of Inclusive Education. V. 15, No. 3.

[12] Cagran B., Schmidt M. (2011) Attitudes of Slovene teachers towards the inclusion of students with different types of special needs in primary school//Educational Studies. V. 37, No. 2.

[13] Kharlamov, I.F. (1999) Pedagogics. M.: Gardarika, 520 pages.

[14] Kagan, S. (2013). Kagan Cooperative Learning Structures. San Clemente, CA: Kagan Publishing URL: 〈https://www.kaganonline.com> (date of the address on April 14, 2017) 